\title{
TANTANGAN PENULISAN SEJARAH LOKAL
}

\author{
Warto \\ Jurusan Sejarah, Universitas Sebelas Maret
}

\begin{abstract}
Abstrak: Sejarah lokal selalu menarik diperbincangan karena dua hal. Pertama, batasan "lokal" cukup problematis karena selalu mengalami perubahan cakupan dan maknanya. Istilah lokal seringkali dihadapkan atau dipertentangkan dengan supra-lokal (regional, nasional, global). Makna lokalpun tidak statis dan tunggal tetapi selalu berubah sesuai konteks zaman. Oleh karena itu, penulisan sejarah lokal, seperti penulisan unit sejarah lainnya, dihadapkan bukan hanya persoalan kepastian historis yang menuntut tersedianya sumber yang lengkap dan valid, tetapi juga persoalan penjelasan sejarah yang menuntut pendekatan multidimensional dengan kerangka teoritik dan metodologi yang relevan. Di luar persoalan kepastian dan pemaknaan historis, penulisan sejarah lokal juga dihadapkan pada unsur kewajaran sejarah (fairness) yang bersifat non-akademik. Berbagai kepentingan, orientasi filosofis, prasangka ideologis, seringkali menyelinap dengan sengaja ke dalam proses penulisan sejarah lokal. Dengan mengesampingkan persoalan yang disebutkan terakhir ini, penulisan sejarah lokal ke depan harus tetap bertumpu pada prinsip-prinsip teori dan metodologi sejarah kritis agar dapat memberi kontribusi positif bagi pengembangan penulisan sejarah nasional yang bercorak indonesiasentrisme.
\end{abstract}

Kata Kunci: sejarah, lokal, nasional

\begin{abstract}
Firstly, the limitation of local creates some problems. This is caused by the change of scope and meaning. The term of local is also faced with the antonym term of regional, national, or global. The meaning of local is flexible but changes based on the spirit of age. Therefore, the writing of local history faces not only the scarcity of historical sources but also the need of multidimentional approach and relevant theoretical framework and methodology. In addition, the matter of historical fairness contributes to the complexity of historical study. Some interests, philosophical orientation, and ideological prejudice are often to shape the local historiography. Local history writing should be directed into the base of theoretical principles and methodology in order to give positive contribution for develping the writing of national history based on Indonesiacentrism perspective.
\end{abstract}

Keywords: history, local, national

John Naisbitt dalam Global Paradox (1994) menyebutkan adanya kecenderungan paradoksal dalam era globalisasi. Di satu sisi ikatan-ikatan primordial/lama mulai memudar dan digantikan ikatan baru yang melampaui batas-batas primordial. Gejala ini semakin kuat dan meluas berkat adanya perkembangan teknologi informasi dan komunikasi yang mampu mengatasi batasan ruang dan waktu. Terbentuklah apa yang disebut "desa global" di mana para penghuninya disatukan melalui jaringan komunikasi modern. Namun, di sisi lain, di tengah arus globalisasi yang semakin deras mengubah tatanan lama dan ikatan-ikatan primordial, muncul gerakan kembali ke yang "lokal" da- lam rangka menemukan dan menegaskan identitas masing-masing kelompok primordial. Selain membawa dampak positif, globalisasi tidak jarang dirasakan menjadi ancaman. Globalisasi menyebabkan disorientasi, dislokasi, dan alienasi bagi sebagian masyarakat yang tidak siap menghadapinya. Salah satu cara untuk bertahan hidup di tengah gempuran modernisasi dan globalisasi adalah melalui penegasan dan penguatan kembali identitas primordial. Cara terbaik untuk memenuhi keinginan itu adalah dengan menuliskan sejarah lokalnya untuk memberi kesadaran transendental tentang makna hidupnya. Dalam konteks ini, penulisan sejarah lokal bukan semata- 
mata untuk menghimpun kembali pengalaman individu dan kolektif masa lalu yang penuh kebanggaan dan kejayaan, dan juga bukan untuk memupuk jati diri yang berlebihan, serta bukan untuk membuat dinding-dinding pembatas baru dalam berhadapan dengan yang lain, tetapi untuk mencari akar budaya sebagai dasar pijakan dalam melangkah (Carment, 2013; Magnusson, 2006.

Persoalannya, batasan sejarah lokal sendiri masih menimbulkan perdebatan (Brian, 1999). Sebagian mengatakan bahwa sejarah lokal sama dengan sejarah daerah tertentu atau sejarah suku bangsa dan etnik tertentu, sedangkan yang lain membatasi lingkup sejarah lokal pada aspek sosio-kulturalnya. Pembatasan yang terakhir ini melampaui batasbatas geografis dan wilayah administratif suatu daerah/tertentu, serta lebih menekankan pada batasan kesamaan corak budaya, aktivitas ekonomi, stuktur sosial politik, sistem religi, dll. Peristiwa sejarah yang terjadi di lokasi yang terbatas, misalnya desa atau kota kecil, kurang menarik karena tidak mempunyai dampak luas. Namun, kadangkala sejarah lokal menarik karena mengungkapkan persoalan kemanusiaan secara unik, khusus, dan inspiratif. Pengetahuan lokal yang menunjukkan kecerdasan masyarakat lokal yang mengandung pola-pola tertentu dapat dibandingkan dengan masyarakat lain. Namun, berbeda dengan penulisan sejarah lokal di tempat lain, misalnya, seperti yang dilakukan Le Roy Ladurie dalam The Peasant of Languedoc (1976) dan Montaillou (1978), yang menulis pedesaan Perancis Selatan pada abad ke-14 dengan dukungan dokumen tertulis yang cukup melimpah, penulisan sejarah lokal di Indonesia sulit dilakukan secara baik karena keterbatasan sumber tertulis. Penulisan sejarah lokal dalam lingkup kecil/mikro juga menuntut metodologi khusus atau kerangka konseptual yang halus agar dapat melakukan analisis yang tajam sehingga pola-pola mikro dapat diekstrapolasikan (Sartono Kartodirdjo, 1992: 74). Tulisan ini mendiskusikan beberapa persoalan di sekitar penulisan sejarah lokal di Indonesia, baik yang berkaitan dengan persoalan metodologi, perspektif, dan eksplanasi se- jarah, maupun persoalan kewajaran (fairness) yang sering menyelinap secara halus ke dalam penulisan sejarah. Berbagai aspek ini berpengaruh terhadap corak sejarah lokal yang dihasilkan.

\section{TANTANGAN}

Tahap paling awal penulisan sejarah lokal adalah menemukan sumber-sumber yang dapat dipercaya dan relevan dengan permasalahan yang diajukan, baik sumber tertulis (dokumen/arsip) sezaman, sumber lisan dari orang yang mengalami, maupun sumber-sumber lainnya berupa artefak seperti monumen, bangunan fisik, tradisi lisan, dan situs-situs peninggalan masa lalu. Langkah pertama ini disebut heuristik, yakni mencari dan menggali sumber data sejarah sebanyak mungkin untuk merekonstruksi suatu peristiwa masa lalu yang menjadi focus penelitian. Langkah berikutnya adalah melakukan kritik sumber (intern dan ekstern) untuk membangun fakta-fakta sejarah yang kemudian dianalisis atau diinterpretasikan dan disusun ke dalam kisah. Tahap paling akhir adalah memberi keterangan sejarah (eksplanasi) menurut perspektif tertentu. Jadi, menemukanmengisahkan-menerangkan adalah rangkaian kerja sejarawan dalam merekonstruksi masa lalu yang menjadi pokok kajiannya. Namun, tidak jarang dalam setiap tahap pekerjaannya, sejarawan menghadapi beberapa kesulitan yang menghadang kelancaran tugasnya.

Kesulitan pertama yang dihadapi adalah persoalan menemukan sumber sejarah yang bisa dipertanggungjawabkan. Ketersediaan sumber, keterbacaannya, dan kemampuan memahami isinya adalah masalah pertama yang dihadapi sejarawan. Sumber sejarah lokal sebagian berupa sumber tertulis seperti naskah (babad, hikayat, kronik, tambo), tradisi lisan (folklore) dan artefak/situs. Selain terbatas jumlahnya, keberadaan naskah sebagai produk budaya lokal tidak selalu ditemukan di tempat di mana naskah itu dibuat. Meskipun diketahui tempatnya, sulit dijangkau karena berada di tempat yang jauh. Kesulitan lain, isi 
naskah juga tidak mudah dipahami karena antara fakta dan fiksi berbaur menjadi satu. Sebagian besar naskah lebih banyak memuat unsur-unsur mistis-legendaris daripada unsur-unsur historis. Demikian pula tradisi lisan yang berupa folklor dengan berbagai variannya, lebih banyak menampilkan fakta mental (mentifact) daripada fakta sejarah, sehingga sulit dijadikan sumber sejarah yang memadai.

Berbeda dengan sejarah lisan, tradisi lisan merupakan ingatan kolektif atau individu anggota masyarakat tentang masa lalu yang diwariskan melalui lisan secara turun temurun (Vansina, 1985). Produk tradisi lisan berupa pesan lisan yang didasarkan pada pesan-pesan sebelumnya dari generasi tua. Prosesnya menyangkut transmisi pesan itu dari mulut ke mulut melintasi waktu hingga pesan itu tidak jelas. John Tosh mendefinisikan tradisi lisan sebagai "...a body of knowledge which has been transmitted orally over several generations and is the collective property of the members of a given society" (1984: 182). Dengan demikian pesan lisan tidak bisa diperlakukan sama dengan pesan tertulis yang memiliki bentuk asli dan salinan. Sementara itu, sejarah lisan merupakan tuntutan metodologis historiografi modern yang membutuhkan kesaksian langsung dari pelaku yang mengalami peristiwa sejarah (Tosh, 1984; Thompson, 1989). Tradisi lisan merupakan kenangan yang luas dan unik dari komunitas sejarah, sedangkan sejarah lisan sebagai metode cenderung pada kesaksian para saksi mata sehingga menjadi kenangan hidup atau kenangan langsung. Sama seperti sumber tertulis, tradisi lisan tetap memiliki bias subjektivitas untuk dijadikan sumber sejarah. Untuk itu diperlukan analisis secara teliti untuk mengkritik dan membandingkan serta menyimpulkan. Harus dipisahkan antara konstruksi logis dan unsur kosmologis/pralogis. Namun, pengakuan tradisi lisan sebagai sejarah turut mewujutkan motif egalitarian sejarah lisan yaitu meruntuhkan anggapan banal Orientalis terhadap masyarakat praaksara yang dianggap people without history.
Di samping naskah dan folklor sebagai bagian dari produk budaya lokal, rekonstruksi sejarah lokal dapat memanfaatkan sumber-sumber Belanda yang cukup kaya (Boomgard, 1991). Sudah tentu sumber-sumber ini cenderung bias kepentingan Belanda dan terselip prasangka budaya Barat dalam melihat masyarakat pribumi/lokal. Oleh karena itu, sejarawan harus tetap selektif dan kritis dalam memanfaakan sumber Belanda ini dalam menyusun sejarah lokal. Dalam beberapa segi apa yang ditulis orang asing (Belanda) itu tidak tepat atau bahkan bertolak belakang dengan kenyataan yang sesungguhnya terjadi di masyarakat. Namun bagaimanapun, sumber tertulis yang cukup penting ini tidak bisa ditinggalkan oleh penulis sejarah lokal karena kaya informasi. Beberapa sumber Belanda yang penting antara lain laporan kolonial (Koloniaal Verslag), laporan serah jabatan (Memorie van Overgave), dan arsip lainnya yang dihimpun dalam koleksi Algemeen Secretarie. Selain itu, terdapat koran, majalah, dan terbitan berkala yang sangat bermanfaat untuk penelitian sejarah lokal. Singkatnya, sumber Belanda yang berupa laporan para pegawai Pemerintah Hindia Belanda, perusahaan swasta, para pedagang, misionaris, dan para pelancong, semuanya memberikan informasi tentang dinamika masyarakat Hindia Belanda selama periode kolonial. Tantangannya, selain harus mengetahui tempat arsip-arsip itu disimpan, sejarawan juga harus mampu memahami isinya karena ditulis dalam bahasa asing (Belanda).

Penulisan sejarah lokal periode pasca kemerdekaan relatif diuntungkan oleh tersedianya sumber yang beragam. Hal ini berbeda dengan penulisan sejarah lokal pra-kolonial yang lebih banyak mengandalkan tradisi lisan dalam bentuk folklore dan naskah-naskah lama, atau masa kolonial yang mengandalkan arsip Belanda. Penulisan sejarah lokal sesudah kemerdekaan dapat memanfaatkan berbagai jenis dokumen/arsip, koran, majalah, memoar, dan pelaku sejarah (sejarah lisan) yang masih hidup. Namun, sejarah lisan seringkali menjadi masalah dalam menuliskan se- 
jarah lokal baik menyangkut daya ingat para informan dan kesediannya memberi informasi secara jujur dan terbuka. Apa yang diingat dan disampaikan para pelaku sejarah tidak selalu sama dengan apa yang dikehendaki dalam penulisan sejarah yang telah mengalami glorifikasi ataupun mitologisasi.

Rekonstruksi sejarah lokal mencakup aspek prosesual dan struktural. Aspek prosesual dalam sejarah berusaha mendeskripsikan kejadian/ deskriptif-naratif yakni menjawab pertanyaan bagaimanakah sesuatu itu terjadi. Urutan kejadian diuraikan secara lengkap dengan fakta-faktanya menyangkut apa, siapa, kapan, dan di mana dalam suatu kesatuan uraian yang menggambarkan perkembangan kejadian. Urutan kejadian secara kronologis, hubungan sebab-akibat, dan motivasi para pelaku merupakan suatu kompleksitas kejadian tersusun untuk menjawab pertanyaan "bagaimana". Setiap karya sejarah harus memuat unsur prosesual ini sebagai esensi uraian sejarah. Di samping itu, perlu juga diuangkap latar belakang kejadian, kondisi dan setting ekonomis, sosial, politik dan kultural yang kesemuanya menunjukkan keadaan "statis" karena bersifat struktural. Misalnya, struktur ekologis, stratifikasi sosial, struktur kekuasaan, orientasi normatif dan nilai-nilai. Kerangka struktural penting diungkapkan agar sejarawan dapat melakukan analisis secara kritis sehingga pertanyaan "mengapa" suatu peristiwa bisa terjadi seperti ini dapat dijawab (Sartono Kartodirdjo, 1992: 114-115). Namun harus diingat, sejarah struktural membawa implikasi metodologis yaitu pendekatan analitis dan multidimensional. Melalui pendekatan seperti ini, kompleksitas perubahan masyarakat dapat dianalisis, misalnya perubahan tingkat makro pengaruhnya di tingkat mikro/lokal, atau sebaliknya kejadian mikro merupakan letupan di tingkat makro. Dengan demikian menjadi jelas bahwa penulisan sejarah lokal tidak cukup hanya dilakukan dengan pendekatan konvensional yang menekankan pada prosesual kejadian dan bersifat deskriptif-naratif, tetapi juga harus memperhitungkan aspek struktural suatu kejadian agar sejarah lokal dapat dianalisis secara multidimensional (deskriptifanalitis).

Lalu bagaimana rekonstruksi sejarah lokal harus dirumuskan. Penulisan sejarah lokal biasanya berangkat dari perspektif nasional atau perspektif para elit penguasa di pusat. Peristiwa lokal atau daerah hanya dianggap penting apabila mempunyai makna nasional atau sejalan dengan perspektif para elit penguasa. Maka seringkali peristiwa lokal hanya diperlakukan sebagai ilustrasi dari masalah di pusat. Bahkan, beberapa peristiwa lokal terpisah atau ditiadakan dari wacana sejarah nasional/pusat. Ada dua "perspektif" atau titik tolak dalam usaha rekonstruksi sejarah yaitu national concern dan lokal perspective (Abdullah, 2001: 104). Perspektif yang pertama berkaitan dengan "ide yang menyebar", sedangkan yang kedua berhubungan dengan dinamika lokal yang berhadapan dengan "ide" tersebut. Dinamika lokal bisa merupakan cerminan dari keharusan pusat, tetapi bisa juga bersifat otonom dan otentik, meskipun idenya terpengaruh dari luar. Lokal sama sekali bukan replika pusat tetapi mempunyai dinamikanya sendiri.

Suatu peristiwa tertentu yang terjadi di daerah/lokal masih diingat oleh sebagian orang yang mengalaminya. Ingatan ini bersifat subjektif, pribadi, bebas, dan otentik, tetapi terbatas. Hanya pengalaman yang membekas saja yang kemudian menjadi ingatan bersama/kolektif. Namun, ingatan yang bebas ini seringkali berhadapan dengan kekuatan mitos yang aktual, integratif, dan hegemonik. Mitos integratif ini yang sering didukung alat pengingat seperti monumen, tugu, diorama, serta diaktualkan melalui upacara peringatan, dapat meniadakan validitas. Ingatanpun akhirnya kesulitan mencari tempat dalam sejarah. Namun, mitos, berbeda dengan sejarah, hanya memberi suasana riil dan kredibel terhadap tatanan, tapi tidak memberikan kearifan. Untuk memperoleh kearifan kita harus berpaling ke sejarah, yakni rekonstruksi masa lalu yang dilakukan secara kritis. Sejarah ada sebagai hasil sebuah 
keputusan yang sengaja dibuat atau disusun melalui penelitian. Oleh karena itu sejarah sangat toleran dan tidak takut terhadap subversif ingatan karena sejarah terbuka untuk memperbaiki diri. Jadi, apa yang tidak tertulis bisa sama pentingnya dengan yang tertulis. Dengan sifatnya yang toleran inilah sejarah harus menolak legitimasi mitos sebagai prisma untuk melihat masa lalu. Kata Abdullah: "ingatan membebaskan sejarah dari kemungkinan terjerumus kepada alam mitos, sebaliknya sejarah membebaskan ingatan dari "tirani" mitos" (107). Dalam istilah lain, ingatan atau memori itu menubuh (embodied) sedangkan sejarah itu menempel (embedded). Sejarah seringkali berambisi mensubordinasikan atau bahkan menghancurkan memori. Maka muncullah apa yang disebut "sites of memory", yaitu penanda ingatan masa lalu namun dalam tatapan atau kendali sejarah. Memori tidak lagi bersifat spontan dan naluriah tetapi menjadi bagian dari "duty of remember" (Budiawan, 2013: x-xi). Memori komunitas lokal, yang seharusnya menawarkan kearifan berhadapan dengan mitos yang hegemonik dan pemikiran yang ahistoris dan anakronistis.

Langkah terakhir penulisan sejarah lokal adalah memberi keterangan atau penjelasan sejarah (eksplanasi). Menurut Kuntowijoyo, penjelasan sejarah meliputi penafsiran dan pengertian suatu kejadian, penjelasan tentang waktu yang memanjang, dan penjelasan tentang peristiwa tunggal. Jadi eksplanasi sejarah bukan hanya berkaitan dengan penjelasan kausalitas suatu kejadian tetapi berkaitan dengan banyak hal. Ada enam kaidah penjelasan sejarah yaitu regularitas (cara menjelaskan hubungan kausal antarperistiwa), generalisasi (konseptual dan kausal), memakai inferensi statistik, pembagian waktu (geografis, sosial, peristiwa), sejarah naratif, dan perspektif sejarawan (Kuntowijoyo, 2008: 10-18). Penulisan sejarah lokal bisa menggunakan satu atau lebih model penjelasan sejarah ini berdasarkan data yang otentik dan terpercaya. Namun, ketika data yang tersedia hanya berupa tradisi lisan, sulit bagi sejarawan membuat penafsiran suatu kejadian tertentu di tingkat lokal.
Persoalan lain yang dihadapi penulisan sejarah lokal adalah persoalan "kewajaran" (fairness) sejarah. Banyak daerah atau tokoh menuliskan sejarahnya untuk bermacam-macam tujuan. Sejarah hari jadi suatu daerah (kabupaten, kota) dapat dijadikan contoh. Banyak daerah ingin mengetahui sejarah hari jadi untuk memperkuat identitas, memupuk kebanggaan daerah, menonjolkan tokoh, dan bahkan untuk melegitimasi pemimpin yang sedang berkuasa. Keinginan menonjolkan identititas daerah dilakukan dengan menggali sejarah lokal sebagai sumber informasi dan referensi. Para pemimpin daerah banyak berperan dalam menentukan corak penulisan sejarah lokal, baik dalam hal menentukan kepastian tanggal lahir/hari jadi daerahnya, peristiwa-peristiwa yang ditonjolkan, pemimpin/tokoh-tokoh yang ditampilkan, dan tujuan penulisan yang sesuai dengan visi kepala daerah yang sedang memimpin. Maka tidak jarang, dalam menentukan tanggal/hari jadi suatu daerah, peneliti menawarkan tiga atau lebih alternatif untuk dipilih pemesannya: tahun yang paling tua/kuna, masa pemerintahan Hindia Belanda, atau masa kemerdekaan. Pada umumnya, periode yang paling kuna-lah yang dipilih untuk menetapkan tanggal hari jadi. Namun, pilihan ini sangat lemah pertanggungjawaban ilmiahnya karena sumbernya terbatas dan kadang-kadang dasarnya hanya folklor. Tidak ada sumber tertulis yang ditemukan. Sementara itu, bila periode kolonial (pemerintahan Hindia Belanda) yang dipilih, dianggap kurang nasionalis, meskipun terdapat dokumen pendukung untuk menentukan kepastian historis tanggal hari jadi. Meskipun demikian, hanya sedikit saja mereka yang memilih periode pasca-kemerdekaan sebagai titik tolak menentukan hari jadi suatu daerah.

Tantangan lainnya adalah pengendalian sejarah. Penulisan sejarah dapat dilakukan oleh siapa saja yang merasa bisa dan mampu melakukan. Namun, seringkali justru penulisan sejarah dikendalikan oleh mereka yang punya kekuatan dan kekuasaan. Mereka yang mempunyai sumberdaya ekonomi terutama dana untuk membiayai penelitian sejarah lokal sangat menentukan pilihan 
topik yang diteliti dan hasil yang diharapkan. Dengan kekuatan dana dan fasilitas lain yang dimiliki, seseorang atau lembaga pemerintah mampu mengarahkan penulisan sejarah lokal untuk kepentingan tertentu. Sebab, tanpa adanya pengendalian sejarah, hasil penelitian sejarah lokal bisa jadi dapat mendelegitimasikan kedudukan penguasa lokal atau dapat memecah belah kehidupan bersama dalam komunitas itu. Bahkan, sejarah lokal juga dapat dimanfaatkan sebagai alat legitimasi. Nikita Krushchev (1894-1961) pernah mengatakan, "sejarawan adalah satu-satunya kelompok yang bisa mempertanyakan legitimasi penguasa".

Persoalan berikutnya adalah hubungan lokal - supralokal. Dalam skala yang lebih besar, pola hubungan ini sama seperti hubungan antara Belanda dan daerah koloni di masa lalu, yaitu hubungan antara superior-inferior, supraordinatsubordinat, beradab-terbelakang, dan hubungan asimetris lainnya. Hubungan seperti itu terefleksikan dalam penulisan sejarah yang bias perspektif kolonial: Barat dipandang maju/modern dibanding daerah jajahan yang terbelakang. Historiografi seperti inilah yang kemudian dikeluhkan van Leur ketika ia berucap bahwa "sejarah Indonesia hanya ditulis di atas geladak kapal dan benteng VOC" sehingga dinamika masyarakat Hindia tidak pernah ditangkap dengan jelas. Analog dengan ini, penulisan sejarah lokal kita masih dibayangbayangi sejarah nasional yang cenderung atau terpaksa meninggalkan/melupakan sejarah lokal. Narasi-narasi kecil yang sesungguhnya sangat bermakna dipandang kurang penting bagi kepentingan nasional sehingga tidak menjadi bagian dari sejarah nasional. Sejarah lokal yang hanya dilihat dari singgasana kekuasaan pusat kurang berhasil merepresentasikan dinamika lokal yang sesungguhnya. Maka ketika ia dianggap tidak bermakna secara nasional, atau bahkan bertentangan dengan visi penguasa, narasi-narasi lokal dengan mudah disingkirkan. Sejarah lokal sesungguhnya dapat menjadi penyeimbang historiografi nasional yang kadang-kadang sangat elitis dan bias kepentingan rezim yang berkuasa. Sejarah lokal sesungguhnya dapat menjadi sarana untuk mengoreksi hubungan nasional-lokal yang hegemonik dan subordinatif.

\section{CATATAN AKHIR}

Penulisan sejarah lokal menuntut persyaratan seperti layaknya menulis sejarah pada umumnya. Sejalan dengan tuntutan perkembangan teori dan metodologi sejarah, penulisan sejarah lokal tidak cukup hanya dilakukan dengan pendekatan deskripti-naratif, tetapi perlu menggunakan pendekatan kritis. Corak penulisan sejarah lokal yang hanya memberi jawaban atas pertanyaanpertanyaan elementer yang sifatnya kronik kurang memadai atau bahkan tidak relevan lagi bagi kepentingan penelitian sejarah modern. Agar penulisan sejarah lokal terhindar dari corak kronik, pendekatan kritis harus dilakukan agar aspekaspek struktural suatu peritiwa itu dapat dijelaskan. Dengan demikian sejarah bukan sekedar bercerita hal-hal yang elementer, meskipun ini penting untuk memperoleh kepastian historis, tetapi juga dapat menerangkan hubungan sebab-akibat dan faktor-faktor struktural lainnya yang turut menentukan jalannya sejarah lokal. Namun, terbatasnya sumber sejarah lokal yang umumnya berupa tradisi lisan menyulitkan penulisan sejarah lokal secara kritis. Tradisi lisan lebih banyak menginformasikan mentifact daripada sociofact dan artifact sehingga aspek-aspek prosesual dan struktural sulit dilacak. Di samping itu, sumber tertulis dalam bentuk naskah juga tidak serta merta dapat dimanfaatkan karena keterbatasan kemampuan memahami isinya. Naskah yang ditulis dalam bahasa daerah dan huruf non-latin tidak lagi diakrabi oleh sejarawan yang menulis sejarah lokal. Akibatnya, gambaran sejarah lokal hanya dapat diungkap secara terbatas, samar-samar dan terpenggal-penggal. Tanpa berbekal kemampuan membaca naskah yang baik, sulit menuliskan sejarah lokal menurut perspektif komunitas lokal. Oleh karena itu, pelu terus digalakkan kemampuan membaca dan me- 
mahami sumber-sumber lokal (dan juga asing) dalam segala bentuknya agar penulisan sejarah lokal secara kritis dapat dilakukan. Tanpa langkah nyata yang demikian, penulisan sejarah lokal akan terjebak ke dalam kungkungan mitos dan ingatan yang jauh dari sejarah yang menawarkan kearifan.

\section{DAFTAR RUJUKAN}

Abdullah, T. 2001. Nasionalisme \& Sejarah, Bandung: Satya Historika.

Boomgaard, P. (ed.). 1991. The Colonial Past: Dutch sources on Indonesian history, The Netherlands: Royal Tropical Institute.

Budiawan (ed,). 2013. Sejarah dan Memori: titik simpang dan titik temu, Yogyakarta: Ombak.

Carment, D. 2013. "for their own purposes of identity': Tom Stannage and Australian Local History", Public History Review, vol. 20, pp. 68-79.

Edwards, B. 1999. "The Trouble with Local History", Regional Historian, Issue 3, Spring, pp.1-3.

Ladurie, E. L. R. 1976. The Peasants of Languedoc, Urbana-Chicago-London: University of Illinois Press.

(1978), Montaillou: The world-famous portrait of live in a Medieval Village, Penguin Books.

Magnusson, S.G. 2006. "Rethinking Home. A Case for Writing Local History (review)", Journal of Social History, Vol. 40, No. 2, pp. 518-520.

Kartodirdjo, S. 1992. Pendekatan Ilmu Sosial dalam Metodologi Sejarah, Jakarta: Gramedia.

Thompson, P. 1988. The Voice of The Past: Oral History, Oxford-New York: Oxford University Press.

Tosh, J. 1982. The Pursuit of History, London and New York: Longman.
Vansina, J. 1985. Oral Tradistion as History, London: James Currey. 